\title{
ACHILES: AN IMORTAL EPONYMOUS
}

\section{AQUILES: UM EPÔNIMO IMORTAL}

\author{
Nacime Salomão barbachan Mansur ${ }^{1}$ (i), Marcel Jun Sugawara Tamaoki ${ }^{1}$ (i) \\ 1. Federal University of Sao Paulo, Paulista School of Medicine, Department of Orthopedics and Traumatology, São Paulo, SP, Brazil.
}

\section{ABSTRACT}

The conditions affecting the calcaneal tendon remain extremely prevalent in the clinical practice. The search for information about these diseases in national and international scientific databases are commonly hampered in the use of search tools, requiring the use if an eponym in the strategy. Achilles, in reference to the hero of the Greek mythology, is often used by several authors in scientific publications despite the new Nomina Anatomica. Objective: This article intends to recover the history behind the use of this term, which heroically resists in the clinical discussions of everyday life in articles and textbooks. Level of Evidence V, Literature Review.

Keywords: Achiles Tendon. History of Medicine. Terminology. Anatomy.

\section{RESUMO}

As afecções que afetam o tendão calcâneo permanecem extremamente prevalentes na prática clínica. A busca por informações sobre essas doenças na produção científica nacional e internacional comumente esbarra em uma dificuldade na utilização das ferramentas de procura e na necessidade de acrescentar um epônimo na estratégia. Aquiles, em referência ao herói da mitologia grega, éfrequentemente empregado por diversos autores em suas publicações científicas a despeito da nova nômina anatômica. Objetivo: Esse artigo busca resgatar a história da utilização desse termo, que resiste heroicamente tanto nas discussões clínicas do cotidiano quanto nos artigos e livros-texto. Nível de Evidência V, Revisão da Literatura.

Descritores: Tendão do Calcâneo. História da Medicina. Terminologia. Anatomia.

Citation: Mansur NSB, Tamaoki MJS. Achiles: an imortal eponymous. Acta Ortop Bras. [online]. 2020;28(6):316-317. Available from URL: http://www.scielo.br/aob.

Achilles turned his back to Troy and raised his hand in triumph. Seeing his chance, Paris let fly his arrow. It flew as a hawk flies to make its kill - remorseless, eager, unchangeable. Then, it began

to dip toward the ground and lose power. Yet, still flew straight and deadly. Achilles had been protected from the weapons of men since his mother dipped him in the dark waters of the River Styx. Now, the arrow found the only place that Thetis' fingers covered, letting it untouched by the turbulent waters. The arrow stroked hard Achilles' heel, killing him.

lliad, Homer. ${ }^{1}$

The calcaneal tendon is the strongest and thickest tendon unit in the human body. It is also called Achilles in reference to the Greek mythological hero who, according to the authors of antiquity, was held by this anatomical region when being dipped in the River Styx. Thetis, his mother, trying to make her son immortal by submerging him, would have left that part vulnerable. Achilles was killed by Paris with a poisoned arrow right at that region. This mythological passage rose the expression "Achilles' heel" widely used when referring to the weak point of a person or object. ${ }^{2,3}$

Homer, around the 8th century BC, writes Iliad, one of the epic poems of ancient Greece, in which he narrates the events of the 51 last days of the Trojan War. In this part of the epic, he introduces the warrior Achilles, Greek hero and protagonist of the play. Iliad deals with the wrath of Achilles. Such wrath is caused by a dispute between him and Agamemnon, commander of the Greek armies in Troy, and it is consummated with the death of the Trojan hero Hector. Achilles, betrayed by Agamemnon, decides to abandon the war, but returns to battle after his great friend Patroclus is killed by Hector. The hero avenges his colleague by murdering Hector. ${ }^{1}$

The word Achilles is originated from the combination of the expressions "grief or pain"(achos) and "people" (laos), which can be interpreted as an embodiment of the suffering of people. It became a common name in antiquity, frequent in mythological stories. The hero Achilles appears in several literary works after the lliad, mainly in later centuries, becoming a figure of numerous frescoes, sculptures, and plastic productions in the three millennia following his original appearance. Achilles is a character widely manifested nowadays, as a highlight of ancestral and contemporary culture. ${ }^{4}$ Statius, around the year I AD, writes The Achilleid and addresses the birth of the hero, giving rise to the myth of his vulnerable spot. His mother, Thetis, shortly after the birth of her son, would have plunged him into the River Styx in an attempt to make him immortal. However, she had held the child by his heel, a region that was not submerged, thus, this place became his zone of weakness. According to Statius, the hero would later be killed with a poisoned arrow thrown at his heel by Paris. The myth of the unbeatable warrior

All authors declare no potential conflict of interest related to this article.

The study was conducted at Universidade Federal de São Paulo, Paulista School of Medicine, Department of Orthopedics and Traumatology.

Correspondence: Nacime Salomão Barbachan Mansur. Rua Napoleão de Barros, 715, 1 andar, Vila Clementino, São Paulo, SP, Brazil, 04024001. nacime@nacime.com.br

Article received on 04/23/2020, approved on 06/24/2020. 
shot down with a vulnerable spot gained intensity over the course of human history, classically referred to as the fragility zone of an individual or item. ${ }^{5}$

The omnipresence of Achilles in popular folklore reached medicine, and the warrior became eponymous of the posterior and distal topography of the leg, particularly the tendon that connects the calf muscle to the heel bone. This nickname was attributed by Philip Verheyen, flamenco surgeon, who, in 1693, published the book Corporis Humani Anatomia and associated this structure with the mythological hero in the 13th chapter of its second edition. Unofficial sources also indicate that this attribution was carried out by Verheyen (1699) after dissecting his own leg amputated due to gangrene. Jean-Louis Petit, in 1705, connects the terms "tendon" and "Achilles" in his work L'art de Guerir les Maladies des Os. Lorenz Heister, in his Compendium Anatomicum, from 1717, uses the Latin expression tendo Achillis for the first time in history when describing the insertion of the calcaneal tendon. The author uses the term again in a case report of an Achilles tendon suture. ${ }^{6-10}$

Thus, this nomina was widely used in the 18th century by several anatomists. In the subsequent century, virtually all previous denominations were abandoned, increasing the use of tendo Achillis. However, it was only after the creation of the Anatomical Society in 1895 that this terminology was proclaimed at the Basiliensia Nomina Anatomica congress. Following some minor changes over the decades, the historical term was finally deconsecrated, in 1998, by the Anatomical Terminology, and it was replaced by tendo calcaneus. According to the Committee, the use of the cultural reference Achilles should be done exclusively on an unofficial level. Despite the norm, the term "Achilles tendon" remains in the modern medical and orthopedic literature, being found routinely in scientific articles and books. ${ }^{9,11,12}$

Hippocrates (460-377 BC) may have been the first in history to refer to the calcaneal tendon as neura megala. Neuron was used to describe both tendons and nerves as commonly occurred in ancient Greece. The translation of Greek into Latin incorporated the concept of nervus, and this tendon was described by Ruphus (60-120 AD) as nervus latus or nervus crassus. Avicenna (980-1037 A.D.), by the translations of Cremonensis (1114-1187 AD), uses the term chorda magna Hippocratis, an expression shared with the one from Ruphus in the following centuries. It was only with Vesalius, in his work De Corporis Humani Fabrica Libri Septem, 1543, that the term tendon (tendo) designates tendon structures. Paré, in 1579, uses the term tendon du talon and Verheyen in 1693, creates chorda Achillis, being followed by the others, as previously reported in this chapter. The word calcaneal is originated from the Latin word calx, which can be translated as limestone. It was used for the probable similarity of the bone to this ore, sometimes being designated as posterior projection or spur of the foot. ${ }^{9,13-18}$

Although the term "calcaneal tendon" is supported by the official anatomical norm, the official name of this structure is not the most used either at the formal or informal level. This practice might be attributed to the necessity professionals have to differentiate the calcaneus bone from the Achilles tendon in daily practice. Still, the tradition of using eponyms and the attractive historical rescue brought by the use of this mythological reference still greatly influence its utilization. Nevertheless, it is still interesting to observe the evolution of its nomenclature and how much it survives in modern times. Achilles still lives.

AUTHORS' CONTRIBUTIONS: Each author contributed individually and significantly to the development of this article. NSBM: literature review, study conception, and writing of the manuscript; MJST: conception of the study and revision of the text.

\section{REFERENCES}

1. Homero. Ilíada. Lourenço F, translator. São Paulo: Penguin Companhia; 2013

2. Cohen JC. Anatomy and biomechanical aspects of the gastrocsoleus complex. Foot Ankle Clin. 2009;14(4):617-26.

3. Doral MN, Alam M, Bozkurt M, Turhan E, Atay OA, Dönmez G, et al. Functional anatomy of the Achilles tendon. Knee Surg Sports Traumatol Arthrosc. 2010;18(5):638-43

4. Colombo IC. Heroes Achilleus: Theos Apollon. Rome: Bruno Gentili \& Giuseppe Paione; 1917.

5. Estácio PP, Moreira DDS. Estácio, “Aquileida”, I.318-337, apresentação e tradução. Sci Traductionis. 2016;(16):184-8.

6. Bezerra AJC. Admirável mundo médico. 3rd ed. Brasília (DF): CRM-DF; 2006.

7. Petit JL. L'art de guerir des maladies des os. Paris: L. d'Houry; 1705.

8. Heister L. Compendium anatomicum. Altdorf: J. G. Kohlesius; 1717.

9. Musil V, Stingl J, Bacova T, Baca V, Kachlik D. Achilles tendon: the 305th anniversary of the French priority on the introduction of the famous anatomical eponym. Surg Radiol Anat. 2011;33(5):421-7.
10. Verheyen P. Corporis humani anatomia. Fritsch: Lipsiae; 1699.

11. Federative Committee on Anatomical Terminology. Terminologia Anatomica. Stuttgart: Thieme; 1998.

12. Donath T. Anatomical dictionary with nomenclatures and explanatory notes. Oxford: Pergamon Press; 1969.

13. Diab M. Lexicon of Orthopaedic Etymology. CRC Press; 1999.

14. Hyrtl J. Onomatologia anatomica. Wien: W. Braumuler; 1880.

15. Kachlik D, Musil V, Vasko S, Klaue K, Stingi J, Baca V. Calcaneus, calcaneal tendon and retrocalcaneal bursa: historical overview and plea for an accurate terminology. Acta Chir Belg. 2010;110(2):255-60.

16. Kelikian AS. Sarrafian's anatomy of the foot and ankle. 3rd ed. Philadelphia: Lippincott Williams \& Wilkins; 2011.

17. Klenerman L. The early history of tendo Achillis and its rupture. J Bone Joint Surg Br. 2007;89-B(4):545-7.

18. Vesalius A. De humani corporis fabrica libri septem. Basileae: Ex Officina Joannis Opporini; 1543. 